\title{
STRUCTURE AND DYNAMICS OF OLIGOMESIC DRY PINE FORESTS IN LAND ZONES OF THE LAKE ENGURE CATCHMENT AREA
}

\author{
Māris Laiviņš*, Gunta Čekstere*, Anda Medene*, and Jānis Donis** \\ * Institute of Biology, University of Latvia, Miera iela 3, Salaspils, LV-2169, LATVIA; \\ m.laivins@inbox.lv; guntac@inox.Iv; andamedene@inbox.lv \\ ** Latvian State Forest Research Institute "Silava", Rīgas iela 111, Salaspils, LV-2169, LATVIA; \\ janis.donis@silava.Iv
}

Communicated by Viesturs Melecis

\begin{abstract}
Investigation of species composition, soil physical and chemical properties, as well as forest productivity of oligomesic dry pine forests (Vacciniosa and Myrtillosa forest types) was carried out in six dry land zones differing in age of the Lake Engure catchment area (sediment zones of the drained lakebed, Mia, Limnea, Litorina Sea, Baltic Ice Lake and glaciofluvial sediment zone in Northern Kursa Upland). Higher species diversity in the tree layer and a more typical podzolisation process was found in the older dry land zones (sediments of the Baltic Ice Lake, Northern Kursa Upland), while higher species diversity in the field layer (higher proportion of grasses and sword grasses), more intensive gleying process in soils, as well as considerably higher stand productivity was observed in the younger dry land zones (the drained lakebed, Mia, Limnea and Littorina Sea stages). Characteristic species of the Vaccinio-Piceetea class were dominant in the pine forests of older dry land zones, whereas species of the Pulsatillo-Pinetea class were typical in the sea coastal pine forests.
\end{abstract}

Key words: land zone, Pinus sylvestris, forest productivity, soil.

\section{INTRODUCTION}

Several land zones of different ages are found in the Lake Engure catchment area $\left(677 \mathrm{~km}^{2}, 1 \%\right.$ of the area of Latvia) from coastal areas to inland areas, parallel to the sea coast. They formed in the Northern Kursa Upland as a result of the degradation of the last glacial cover, changes in different developmental stages of the Baltic Ice Lake and the Baltic Sea during the Holocene (Littorina, Limnea, and Mia Sea stage), as well as the decrease of the water level in Lake Engure 170 years ago (1841). As the result, a wide drained zone of the lakebed around the lake was formed (Buharts, 1935; Danilāns, 1995; Eberhards and Saltupe, 2000; Zelčs and Markots, 2004; Laivinuš et al., 2012). Each zone has a specific complex of natural features (geological structure/composition, relief geneses, hydrological conditions, vascular plant flora and plant communities), as well as socioeconomic characteristics (territorial structure of population distribution, composition of land use type and landscape mosaic structure) (Strautnieks and Grīne, 2011; 2013; Kurpniece et al., 2013; Laiviņš et al., 2013; Penēze et al., 2013; Rūsina et al., 2013).

Differences in the composition of plant species and plant communities in various dry land zones are best observed in the conservative structures of the geographical landscape the structure of forest stands and their mosaic distribution. Near the sea coast in younger and hypsometrically lower zones with shallower groundwater level there is a greater area of forests growing in wet soils and drained wet soils, which can be characterised as poor with nutrients (46.5-56.2\% of the total forest area). In the older highland zone, there is a considerable proportion of forests with normal soil moisture and higher nutrient content $(76.3 \%)$. Scots pine is the dominant tree species in stands. The proportion of pine trees is more than $55.0 \%$ in the accumulation zone of different age stages of Baltic Sea, but in the older highland zone, pine stands occupy only $27.5 \%$ of the total forest area (Medene, 2012; Laivins et al., 2013).

Oligomesic pine stands (Vacciniosa and Myrtillosa forest types) were studied in regard to stand structure and processes in land zones of various ages. These forest types have the most sensitive reaction to impacts on environmental processes, particularly on eutrophication processes in nutrient poor forest stands (Laiviņš, 1998).

The research hypothesis is that pine forest vegetation of the geologically older section of the drainage basin (the Northern Kursa Upland and Baltic Ice Lake zone) is older and 
more stable in comparison to the geologically younger zones (land zones of the Baltic Sea stages, drained lakebed zone of Lake Engure), where unstable temporary plant communities in the beginning phase of vegetation stabilisation are common (Laiviņš et al., 2012). Coastal vegetation is constantly dynamic due to the influence of various environmental disturbances, in particular from the sea, which can frequently be catastrophic.

The research aim is to determine the plant composition of oligomesic pine stands in the Lake Engure catchment area, as well as the physical and chemical soil properties and differences in forest productivity in dry land zones of different ages.

\section{MATERIAL AND METHODS}

Research sites. Six permanent plots were established for investigation of the structure and dynamics of oligomesic pine forests in land zones of different ages of the Lake Engure catchment area (Fig. 1, Table 1). The permanent plots were distributed in a transect from the sea coast (Bērzciems) to the western border of the drainage basin (Vandzene). The total length of the transect was $25 \mathrm{~km}$.

Sediments of different Baltic Sea development stages (Mia, Limnea, and Littorina Sea), sediments of the drained Engure lakebed, as well as the highest diversity of forest growing conditions (soil moisture, warmth conditions, plant nutrient content in soil) are situated in the narrow land zone $(2-3 \mathrm{~km})$ between the sea and the Lake Engure. The borders between the Littorina, Limnea and Mia Sea sediment zones were not clearly delineated. They were defined based on surface morphometric parameters and relief forms (Eberhards, 2003; Eberhards and Lapinskis, 2008). Two perma-
Table 1

DESCRIPTION OF THE SCOTS PINE FOREST PERMANENT PLOTS IN THE LAKE ENGURE CATCHMENT AREA

\begin{tabular}{|c|c|c|c|c|c|}
\hline \multirow[t]{2}{*}{ Plot } & \multicolumn{2}{|c|}{ Coordinates } & \multirow{2}{*}{$\begin{array}{l}\mathrm{H}, \mathrm{m} \\
\text { asl. }\end{array}$} & \multirow{2}{*}{$\begin{array}{c}\text { Distance } \\
\text { from sea } \\
\mathrm{km}\end{array}$} & \multirow[t]{2}{*}{ Dry land age zones } \\
\hline & $X$ & $\mathrm{Y}$ & & & \\
\hline 1 & 45008 & 6347595 & 1.8 & 0.14 & Mia Sea zone, $\approx 300-400$ year old \\
\hline 2 & 44966 & 6347802 & 3.9 & 0.35 & $\begin{array}{l}\text { Limnea Sea zone, } \approx 2000-3000 \\
\text { year old }\end{array}$ \\
\hline 3 & 44922 & 6347553 & 5.0 & 0.95 & $\begin{array}{l}\text { Littorina Sea zone, } \approx 4000-8000 \\
\text { year old }\end{array}$ \\
\hline 4 & 44822 & 6348820 & 3.4 & 1.65 & Drained lakebed, $\approx 170$ year old \\
\hline 5 & 43400 & 6347584 & 20.3 & 16.00 & $\begin{array}{l}\text { Baltic Ice Lake zone, } \approx 11000 \\
\text { year old }\end{array}$ \\
\hline 6 & 42879 & 6354460 & 37.9 & 19.80 & $\begin{array}{l}\text { Northern Kursa Upland zone, } \approx 13 \\
000 \text { year old }\end{array}$ \\
\hline
\end{tabular}

nent plots were selected to the west of Lake Engure. They represented pine forests of the Baltic Ice Lake zone (near Pliavas) and the zone of glaciofluvial sediments in Northern Kursa Upland (near Vandzene).

The permanent plots in Scots pine forests were established and the research was carried out in May and June 2012 (plots 3-6) and June and July 2013 (plots 1 and 2). The permanent plots were circular with a $15 \mathrm{~m}$ radius and area $706.5 \mathrm{~m}^{2}$. All trees higher than $5 \mathrm{~m}$ were numbered. The geographical coordinates (LKS-92 system) were established by GPS, and distance of the plot from the sea by an ArcView database.

Forest stand parameter inventory in experimental plots. Stand characterisation was done according to several parameters: tree diameter at $1.3 \mathrm{~m}$ height, tree height, length

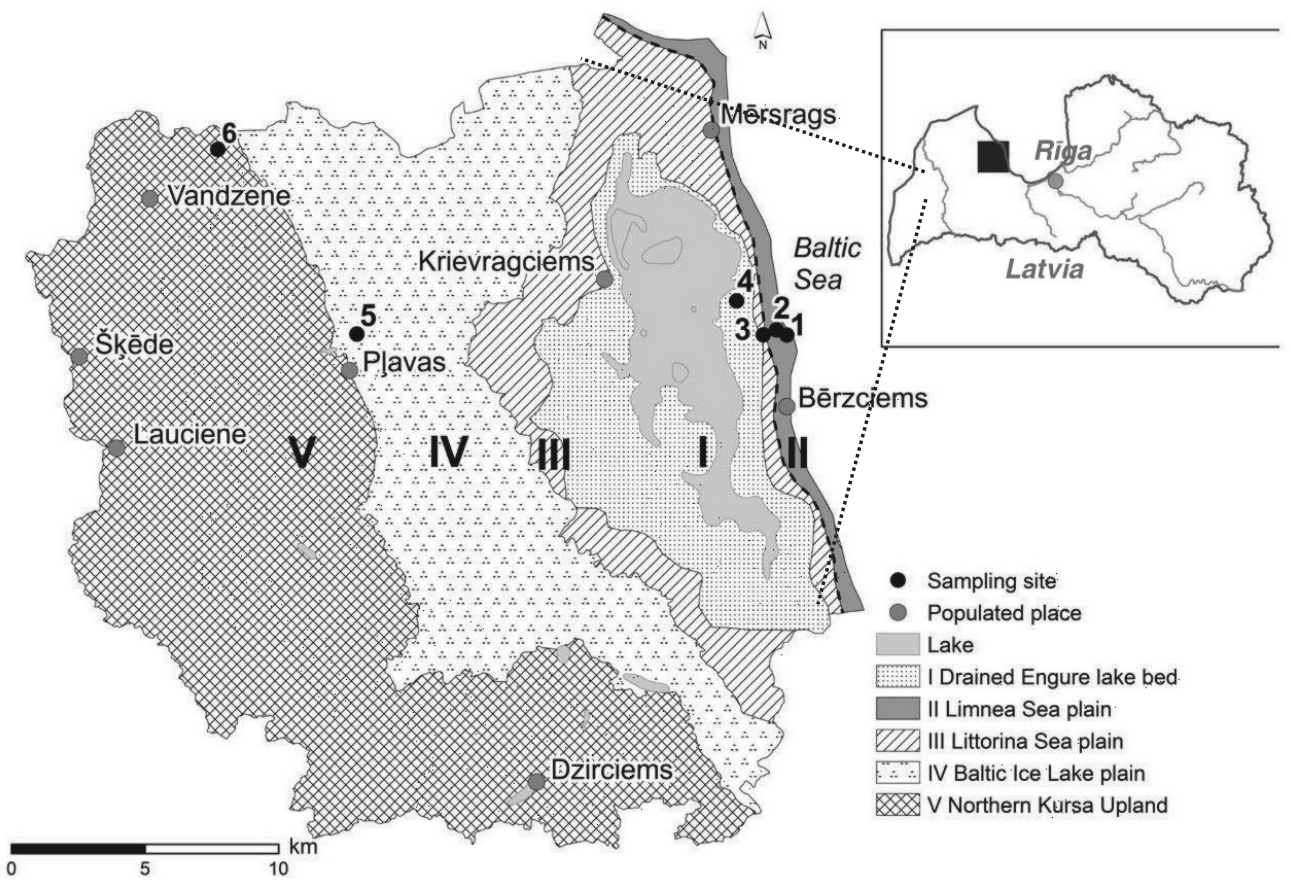

Fig. 1. Location of research area in Latvia and locations of research plots in the Lake Engure catchment area. 
of the longest crown projection and its perpendicular axis, as well as tree azimuth and distance from the plot centre. Tree-ring width samples (wood cores) were taken from at least 12 pine trees per plot with a Presler increment drill. For tree-ring width measurement a LINTAB 4 measuring table and TSAPWIN software was used. Stem width and height was measured also for snags and lying deadwood.

Composition of vascular plant and moss species in each pine stand where plots were located, was inventoried in five $20 \times 20 \mathrm{~m}\left(400 \mathrm{~m}^{2}\right)$ areas. One of them was located in the circular plot area, but the others $25 \mathrm{~m}$ from the plot centre in a north, east, south and west direction. All tree $\left(\mathrm{E}_{3}\right)$, shrub $\left(E_{2}\right)$, herb $\left(E_{1}\right)$ and moss $\left(E_{0}\right)$ layer species were recorded and projective cover of each layer, as well as of each species were evaluated visually (Dierschke 1994). Sociological groups of plant species were separated based on research results in Latvia on sociological affinity of plant community species (Rūsiṇa and Piliksere, 2005; Rūsiņa, 2007; Laiviņš et al., 2008; Буш и Аболинь, 1968). Nomenclature: vascular plants: G. Gavrilova, V. Šulcs (1999), moss: A. Āboliņa (2001), and lichens: A. Piterāns (2001).

A soil pit up to $1 \mathrm{~m}$ depth was dug in each permanent plot. The soil genetic horizons were marked and their structure and characteristics described according to FAO recommendations and the most appropriate field research methods for Latvia conditions (Kārkliņš, 2008). Soil samples were collected from each soil horizon for physical and chemical analysis. Colour was determined for wet and dry soil in the laboratory using the Mansel colour scale.

Soil analysis. Soil acidity in $1 \mathrm{M} \mathrm{KCl}$ extract, hydrolytic soil acidity in $1 \mathrm{M} \mathrm{CH}_{3} \mathrm{COONa}$ extract by Kapen's method, exchangeable bases in $0.1 \mathrm{M} \mathrm{HCl}$ extract by Kapen-Gilkovich's method, organic $\mathrm{C}$ using an element analyser $L E C O$ CR12, and total nitrogen (Ntot) by a modified Kjeldahl's method were determined in the Soil Research Centre of the LSFRI „Silava”. The total organic matter content (coefficient 0.579 ) and $\mathrm{C} / \mathrm{N}$ ratio were calculated. Base saturation was estimated according to Skujāns and Mežals (1964) and Vanmecheln et al. (1997)

Soil texture using a sedimentation and pipettation method was estimated in the Soil Laboratory of the Faculty of Geography and Earth Sciences, University of Latvia. To determine the content of chemical elements $(\mathrm{Ca}, \mathrm{Fe}, \mathrm{Mn}, \mathrm{Ni}, \mathrm{Zn}$, $\mathrm{Cu}, \mathrm{Cd}$, and $\mathrm{Pb}$ ), the soil samples were extracted with $1 \mathrm{M}$ $\mathrm{HCl}$ solution and analysed with an atomic absorption spectrophotometer Analyst 200 (Riņkis and Ramane, 1989; Ринькис и др., 1987). $1 \mathrm{M} \mathrm{HCl}$ extraction characterises not only the amount of element currently available for the plant uptake from the soil, but also indicates the amount of reserves of the element for the remaining vegetation season (Osvalde, 1996).

Statistical analysis. To estimate the ecological conditions of pine stands, Ellenberg indicator values were calculated for the each vegetation relevé and plant community (Ellenberg et al., 1992). The plant community relevés were grouped using the two-way indicator species analysis TWINSPAN (Hill, 1979). Gradients in plant species composition, stand productivity and habitat factors were determined using detrended correspondence analysis (DCA) (McCune and Grace 2002), and soil physical and chemical parameter relationships by principal component analysis (PCA) using PC-ORD Version 5 (McCune and Mefford, 1999). Statistical analysis (correlations, Student's t-test, etc.) of the research results was done using SPSS 14.0 and Excel 2007. Annual growth increments, tree diameter and height measurements in each research plot were used to create and average model tree. Based on the average model tree data the dynamics of pine stock volume (M) were retrospectively calculated according to I. Liepa's (1996) algorithm:

$$
M=\sum \psi H_{i}^{a} D_{i}^{\left(\beta \lg H_{i}+\varphi\right)}
$$

M - stock volume; $\mathrm{m}^{3} / \mathrm{ha}$.

$\mathrm{D}_{\mathrm{i}}$ - individual tree diameter, $\mathrm{cm}$;

$\mathrm{H}_{\mathrm{i}}$ - individual tree height, $\mathrm{m}$;

$\Psi ; \alpha ; \beta ; \varphi-$ coefficients (for pine: $\Psi=0.00016541 ; \alpha=$ $0.56582 ; \beta=0.25924 ; \varphi=1.59689)$.

\section{RESULTS}

Species composition of pine stands. The results revealed that the oligomesic dry pine forests of the Lake Engure catchment area were species poor - a total of 58 vascular plant, epigeous moss and lichen species were observed in 30 relevés, or 15.6 species per relevé. Vaccinio-Piceetea species of boreal forest classes were dominant both by number and coverage (Table 2). In the tree layer a typical edificator species was Pinus sylvestris. Low shrubs like Vaccinium vitis idaea, V. myrtillus, Calluna vulgaris dominated in the field layer. Common mosses were Pleurozium schreberi, Hylocomium splendens, Dicranum polysetum, and Ptilium cirsta-castrensis. Indicator species of boggy forests (Ledum palustre and Vaccinium uliginosum) were frequently observed in the field layer, which indicated elevated moisture level in habitats and boreal conditions in the dry pine forests of the drainage basin.

The most distinct and species rich pine stands (on average 19.4 species per relevé) were identified in the coastal zone. Along with the boreal forest species, pine forest (PulsatilloPinetea) species of dry, warm and calciphilic habitats Chimaphila umbellata, Pyrola chlorantha, Dianthus arenaria, and Thymus serpyllum — were also observed. Such clustering of indicator species of xerophilous pine forests occurred only in the narrow accumulation zone along the seacoast.

Grouping of pine stands by species composition separated four clusters (Fig. 2): 1) the richest pine forests by species number in the coastal accumulative plain (the Mia Sea stage sediments); 2) species poor (on average 12 species per 
Table 2

SPECIES FREQUENCY (\%) IN PERMANENT PLOT (i) RELEVÉS $\left(\mathrm{n}_{\mathrm{i}}=5\right)$

\begin{tabular}{l|c|c|c|c|c|c}
\hline \multicolumn{1}{c|}{ Permanent plot } & 1 & 2 & 3 & 4 & 5 & 6 \\
\hline Cover tree layer E3 (\%) & 35 & 39 & 50 & 72 & 70 & 60 \\
Cover shrub layer E2 (\%) & 1 & 0 & 1 & 1 & 2 & 1 \\
Cover herb layer E1 (\%) & 69 & 66 & 82 & 71 & 72 & 76 \\
Cover moss layer E0) (\%) & 56 & 78 & 88 & 78 & 89 & 86 \\
Number of species & 19.4 & 12.0 & 16.4 & 14.0 & 18.2 & 13.6
\end{tabular}

Ch. Cl. Vaccinio-Pinetea All. Dicrano-Pinion

$\begin{array}{lcccccc}\text { Pinus sylvestris } & 100 & 100 & 100 & 100 & 100 & 100 \\ \text { Vaccinium myrtillus } & 100 & 100 & 100 & 100 & 100 & 100 \\ \text { Vaccinium vitis-idaea } & 100 & 100 & 100 & 100 & 100 & 100 \\ \text { Melampyrum pratense } & 100 & 100 & 100 & 100 & 100 & 100 \\ \text { Pleurozium schreberi } & 100 & 100 & 100 & 100 & 100 & 100 \\ \text { Hylocomium splendens } & 100 & 100 & 100 & 100 & 100 & 100 \\ \text { Calluna vulgaris } & 100 & 80 & 100 & 40 & 100 & 100 \\ \text { Dicranum polysetum } & 20 & 80 & 60 & 100 & 100 & 100 \\ \text { Ptilium crista-castrensis } & 60 & 100 & 100 & 80 & 60 & 20 \\ \text { Deschampsia flexuosa } & 100 & . & 100 & 100 & 100 & 100 \\ \text { Trientalis europaea } & 100 & . & 60 & 40 & . & 60\end{array}$

Ch. Cl. Pulsatillo-Pinetea

Chimaphila umbellata

Pyrola chlorantha

Dianthus arenarius

Thymus serpyllum

Antennaria dioica

Accompanied species

Picea abies

Betula pendula

Sorbus aucuparia

Quercus robur

Aulacomnium palustre

Ledum palustre

Vaccinium uliginosum

Empetrum nigrum

Carex arenaria

Scleropodium purum

Luzula pilosa

Calamagrostis epigeios

Goodyera repens

Juniperus communis

Festuca ovina

Dicranum scoparium

Dryopteris carthusiana

Cladina rangiferina

Agrostis tenuis

Hieracium umbellatum

Galium album

Frangula alnus

Maianthemum bifolim

Populus tremula

Cladina arbuscula

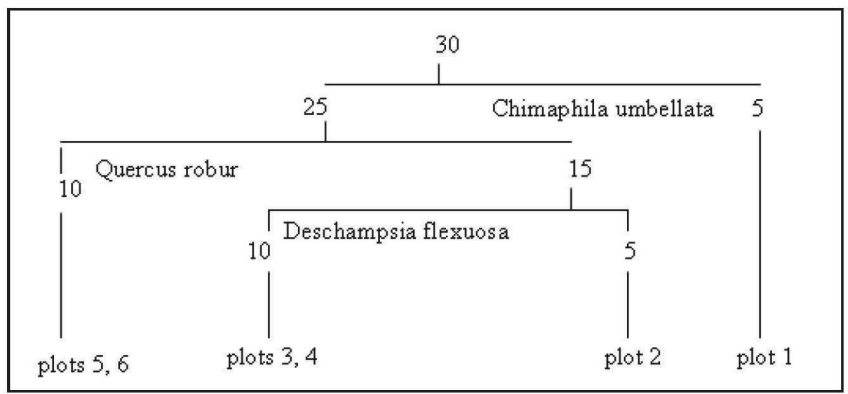

Fig. 2. Vegetation relevé classification of pine forests in the Lake Engure catchment area.

relevé) pine forests in seaside dunes (the Limnea Sea zone and eolic sediments); 3) pine forests of the Littorina Sea sediment zone and drained lakebed; and 4) pine stand vegetation relevés of the Baltic Ice Lake and Northern Kursa Upland. These plant communities reflected gradual changes in the plant and growth conditions of the studied pine stands from the sea coast to inland.

Phytosociological status of the pine forests and ecological habitat potential was characterized by the proportion of sociological groups of plant species in the pine stands of various age stages of land zones. Thus, several sociological groups were identified in the oligomesic pine forests of the Lake Engure catchment area: Cladina gr. (Cladina arbuscula, C. rangiferina); Vaccinium vitis-idaea gr. (Vaccinium vitis-idaea, Calluna vulgaris, Melampyrum pratense, Pleurozium schreberi, Ptilium cirsta-castrensis, Dicranum polysetum); Vaccinium myrtillus gr. (Vaccinium myrtillus, trientalis europaea, Luzula pilosa, Hylocomium splendens); Oxalis acetosella gr. (Maianthemum bifolium, Dryopteris carthusiana); Ledum palustre gr. (Ledum palustre, Vaccinium uliginosum); Antoxanthum odoratum gr. (Agrostis tenuis); Carex arenaria gr. (Carex arenaria, Festuca ovina, Deschapmsia flexuosa); Chimaphila umbellata gr. (Chimaphila umbellata, Thymus serphillum, Dianthus arenaria, Pyrola chlorantha, Anthennaria dioica). The relevance of each sociological group in the species composition was characterised by a sum of species projective cover (Table 3).

Table 3

RELEVANCE INDICATORS OF SOCIOLOGICAL GROUPS OF PLANT SPECIES (SQUARE ROOT TRANSFORMATION OF COVER) IN THE LAKE ENGURE CATCHMENT AREA

\begin{tabular}{l|c|c|c|c|c|c}
\hline \multirow{2}{*}{\begin{tabular}{c} 
Sociological species \\
\multicolumn{1}{c}{ group }
\end{tabular}} & \multicolumn{7}{c}{ Permanent plot } \\
\cline { 2 - 8 } & 1 & 2 & 3 & 4 & 5 & 6 \\
\hline Cladina gr. & 0.7 & 0.0 & 0.7 & 0.0 & 10.0 & 0.0 \\
Vaccinium vitis-idaea gr. & 14.5 & 22.8 & 19.2 & 19.9 & 22.2 & 19.8 \\
Vaccinium myrtillus gr. & 8.7 & 15.2 & 20.4 & 16.9 & 16.1 & 19.9 \\
Oxalis acetosella gr. & 0.0 & 0.0 & 1.0 & 1.2 & 0.0 & 0.0 \\
Ledum palustre gr. & 0.0 & 2.4 & 1.4 & 0.7 & 0.7 & 2.5 \\
Anthoxanthum odoratum gr. & 0.0 & 0.0 & 0.0 & 2.2 & 0.0 & 0.0 \\
Carex arenaria gr. & 14.5 & 1.4 & 5.9 & 9.7 & 7.1 & 4.5 \\
Chimaphila umbellata gr. & 5.3 & 0.0 & 0.0 & 0.0 & 0.0 & 0.0
\end{tabular}


Stand composition and age. Stand structure was determined for middle aged and pre-mature stands of I and II site index (Table 4). The oligomesic pine stands of the catchment area had various ages as the difference between the oldest and youngest tree in the permanent experimental plots was larger than 20 years (except plot 2) and exceeded the interval for one age class.

Currently, the most productive were pre-mature pine stands of I site index in the Littorina Sea zone and the drained lakebed (Table 5) - on average two times higher than stock volume of II site index. It should be noted that natural

Table 4

STAND AGE PARAMETERS OF THE STUDIED PINE FORESTS IN THE LAKE ENGURE CATCHMENT AREA

\begin{tabular}{c|c|c|c|c}
\hline \multirow{2}{*}{ Plot } & \multirow{2}{*}{$\begin{array}{c}\text { Number } \\
\text { of trees }\end{array}$} & \multicolumn{2}{|c|}{ Tree age } & \multirow{2}{*}{$\begin{array}{c}\text { Stand commercial } \\
\text { age }\end{array}$} \\
\cline { 3 - 4 } & 12 & $74-101$ & 91 & Pre-mature \\
\hline 1 & 12 & $59-77$ & 72 & Middle-aged \\
2 & 12 & $66-110$ & 95 & Pre-mature \\
4 & 12 & $67-89$ & 81 & Pre-mature \\
5 & 12 & $59-93$ & 86 & Pre-mature \\
6 & 12 & $45-73$ & 64 & Middle-aged
\end{tabular}

Table 5

STAND CHARACTERIZATION PARAMETERS* IN THE LAKE ENGURE CATCHMENT AREA

\begin{tabular}{|c|c|c|c|c|c|c|c|c|}
\hline $\begin{array}{c}\text { Perma- } \\
\text { nent } \\
\text { plot }\end{array}$ & Status & Species & $\begin{array}{c}\text { Number } \\
\text { of trees }\end{array}$ & $\begin{array}{c}\mathrm{DBH}, \\
\mathrm{cm}\end{array}$ & $\mathrm{H}, \mathrm{m}$ & $\begin{array}{l}\text { Site } \\
\text { index }\end{array}$ & $\begin{array}{c}\mathrm{G}, \\
\mathrm{m}^{2} / \mathrm{ha}\end{array}$ & $\begin{array}{c}\mathrm{V}, \\
\mathrm{m}^{3} / \mathrm{ha}\end{array}$ \\
\hline \multirow[t]{2}{*}{1} & Living & $\begin{array}{l}\text { Scots } \\
\text { pine }\end{array}$ & 396 & 30.6 & 20.6 & II & 31.2 & 319.8 \\
\hline & Snags & $\begin{array}{l}\text { Scots } \\
\text { pine }\end{array}$ & 14 & 12.8 & 12.6 & & 1.82 & 1.2 \\
\hline \multirow[t]{2}{*}{2} & Living & $\begin{array}{l}\text { Scots } \\
\text { pine }\end{array}$ & 722 & 23.6 & 19.4 & II & 33.4 & 318.9 \\
\hline & Snags & $\begin{array}{l}\text { Scots } \\
\text { pine }\end{array}$ & 28 & 13.0 & 11.9 & & 0.62 & 3.99 \\
\hline 3 & Living & $\begin{array}{l}\text { Scots } \\
\text { pine }\end{array}$ & 552 & 31.9 & 26.3 & I & 45.8 & 564.8 \\
\hline \multirow[t]{2}{*}{4} & Living & $\begin{array}{l}\text { Scots } \\
\text { pine }\end{array}$ & 481 & 33.0 & 26.3 & I & 44.1 & 552.7 \\
\hline & Snags & $\begin{array}{l}\text { Scots } \\
\text { pine }\end{array}$ & 14 & 13.4 & 16.4 & & 0.19 & 1.61 \\
\hline \multirow[t]{3}{*}{5} & Living & $\begin{array}{l}\text { Scots } \\
\text { pine }\end{array}$ & 510 & 25.6 & 21.9 & II & 27.5 & 290.7 \\
\hline & Living & $\begin{array}{c}\text { Norway } \\
\text { spruce }\end{array}$ & 28 & 13.5 & 9.5 & & 0.41 & 2.11 \\
\hline & Living & $\begin{array}{l}\text { Silver } \\
\text { birch }\end{array}$ & 14 & 18.0 & 18.8 & & 0.36 & 3.26 \\
\hline \multirow[t]{3}{*}{6} & Living & $\begin{array}{l}\text { Scots } \\
\text { pine }\end{array}$ & 481 & 25.0 & 19.2 & II & 24.6 & 229.8 \\
\hline & Snags & $\begin{array}{l}\text { Scots } \\
\text { pine }\end{array}$ & 28 & 19.6 & 17.0 & & 0.91 & 3.29 \\
\hline & Living & $\begin{array}{c}\text { Norway } \\
\text { spruce }\end{array}$ & 28 & 14.1 & 11.3 & & 0.48 & 3.19 \\
\hline
\end{tabular}

* DBH - diameter at breath height $(1.3 \mathrm{~m})$; $\mathrm{H}$ - tree height; site index - according to Orlov; $\mathrm{G}$ - basal area; V - stem volume mortality was low as only 1-2 snags were counted in some plots.

For each stand, the volume trend for a 50-100 year interval was calculated based on regression equation parameters (Fig. 3). The results revealed that the potentially most productive stands at age 100 years (mature pine stand) occurred in the drained lakebed pine stand (plot 4) $-705.7 \mathrm{~m}^{3}$. The lowest volume at the age of 100 years was in the Mia Sea zone (plot 1) - $339.1 \mathrm{~m}^{3} /$ ha, the Baltic Ice Lake zone (plot 5) - $342.0 \mathrm{~m}^{3} / \mathrm{ha}$, and the Northern Kursa Upland pine stand (plot 6) $-347.9 \mathrm{~m}^{3} /$ ha. Medium volumes in mature pine stands were calculated for the Littorina Sea zone (plot 3) and the Limnea Sea sediment zone (plot 2) - 589.0 $\mathrm{m}^{3} /$ ha and $463.3 \mathrm{~m}^{3} /$ ha, respectively.

Soil. The studied soil profiles clearly had four genetic basic horizons: O, E, B and C, but they were mainly mixed (EC, $\mathrm{CB}$ etc), with gleying features and iron accumulation in lower horizons (Fig. 4). The soils were not structured, friable or with low density/consistence. The average volume density of the organic layer was $\approx 0.2 \mathrm{~g} / \mathrm{cm}^{3}$, and of the mineral soil layer $-\approx 1.2 \mathrm{~g} / \mathrm{cm}^{3}$.

Soil texture. The oligomesic dry forest soils had two main particle fractions: medium and fine sand (Table 6). These comprised more than $90 \%$ of the total fraction in the Engure lakebed and the Limnea and Litorina Sea zone soils, but in the Baltic Ice Lake and Northern Kursa Upland $>80 \%$. Medium sand $(>50 \%)$ was the typical fraction for the forest soils of the Limnea and Litorina Sea parallel dunes, as well as the Northern Kursa Upland soils (Fig. 5). Soil of the Northern Kursa Upland had a higher amount of fine sand, silt and clay particles. The CBsg horizon also contained a

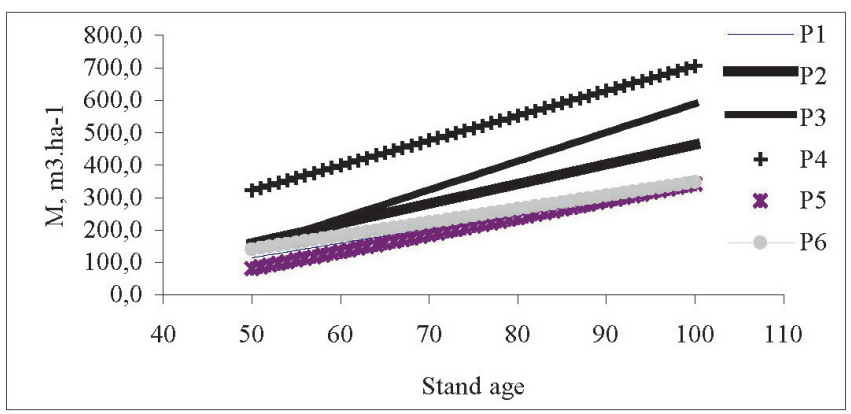

Fig. 3. Pine stand productivity in the permanent plots in the Lake Engure catchment area.

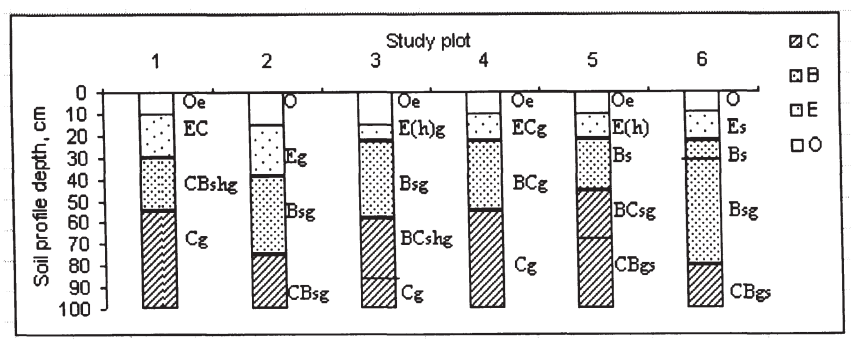

Fig. 4. Soil profiles of the studied Scots pine forests in the Lake Engure catchment area. (Study plots location in land zone: 1 - Mia Sea, 2 Limnea Sea, 3 - Litorina Sea, 4 - drained lakebed, 5 - Baltic Ice Lake, 6 Northern Kursa Upland). 
Table 6

SOIL TEXTURE CHARACTERISTICS (\%) IN THE RESEARCH PLOTS $(n=6)$ IN THE LAKE ENGURE CATCHMENT AREA

\begin{tabular}{|c|c|c|c|c|c|c|c|}
\hline \multirow{2}{*}{$\begin{array}{l}\text { Horizon, } \\
\text { depth, cm }\end{array}$} & \multicolumn{5}{|c|}{ Sand, mm } & \multirow{2}{*}{\begin{tabular}{|c|} 
Silt, mm \\
$0.063-$ \\
0.002
\end{tabular}} & \multirow{2}{*}{\begin{tabular}{|c|}
$\begin{array}{c}\text { Clay, } \\
\mathrm{mm}\end{array}$ \\
$<0.002$
\end{tabular}} \\
\hline & $\begin{array}{c}2.0-1.0 \\
\text { very } \\
\text { coarse }\end{array}$ & $\begin{array}{c}1.0- \\
0.63 \\
\text { coarse }\end{array}$ & $\begin{array}{c}0.63- \\
0.20 \\
\text { medium }\end{array}$ & $\begin{array}{c}0.20- \\
0.125, \\
\text { fine }\end{array}$ & $\begin{array}{c}0.125- \\
0.063 \\
\text { very } \\
\text { fine }\end{array}$ & & \\
\hline \multicolumn{8}{|c|}{ Plot 1} \\
\hline EC 15-25 & 0.0 & 0.0 & 19.7 & 79.3 & 0.8 & 0.1 & 0.1 \\
\hline CBshg 40-50 & 0.0 & 0.0 & 46.1 & 53.5 & 0.2 & 0.1 & 0.1 \\
\hline Cg 70-80 & 0.0 & 0.1 & 58.4 & 41.3 & 1.0 & 0.1 & 0.0 \\
\hline \multicolumn{8}{|c|}{ Plot 2} \\
\hline Eg 20-30 & 0.1 & 5.0 & 87.7 & 6.5 & 0.3 & 0.3 & 0.1 \\
\hline Bsg 45-55 & 0.2 & 0.3 & 81.1 & 18.2 & 0.1 & 0.1 & 0.0 \\
\hline CBsh 80-90 & 0.0 & 2.3 & 92.7 & 4.8 & 0.1 & 0.1 & 0.0 \\
\hline \multicolumn{8}{|c|}{ Plot 3} \\
\hline $\mathrm{E}(\mathrm{h}) \mathrm{g}$ 15-20 & 0.2 & 3.4 & 81.6 & 14.0 & 0.6 & 0.1 & 0.1 \\
\hline Bsg 30-40 & 0.2 & 2.4 & 80.2 & 16.2 & 0.2 & 0.6 & 0.2 \\
\hline BCshg 70-80 & 0.2 & 2.0 & 83.0 & 13.0 & 0.8 & 0.8 & 0.2 \\
\hline Cg 90-100 & 0.0 & 0.2 & 67.0 & 32.2 & 0.2 & 0.2 & 0.2 \\
\hline \multicolumn{8}{|c|}{ Plot 4} \\
\hline ECg 10-20 & 0.0 & 0.2 & 45.6 & 52.2 & 1.4 & 0.5 & 0.1 \\
\hline BCg 35-45 & 0.2 & 0.2 & 41.0 & 55.2 & 1.4 & 1.2 & 0.8 \\
\hline $\mathrm{Cg} 80-90$ & 0.0 & 0.0 & 50.2 & 49.0 & 0.6 & 0.1 & 0.1 \\
\hline \multicolumn{8}{|c|}{ Plot 5} \\
\hline $\mathrm{E}(\mathrm{H}) \mathrm{10}-20$ & 0.8 & 1.8 & 40.8 & 46.4 & 9.2 & 0.9 & 0.1 \\
\hline Bs 25-35 & 0.4 & 1.2 & 40.6 & 48.4 & 7.6 & 1.6 & 0.2 \\
\hline BCsg 50-60 & 1.0 & 1.0 & 8.4 & 74.0 & 15.0 & 0.5 & 0.1 \\
\hline CBgs 85-95 & 0.0 & 0.0 & 8.0 & 81.6 & 9.6 & 0.7 & 0.1 \\
\hline \multicolumn{8}{|c|}{ Plot 6} \\
\hline Es 15-25 & 0.2 & 0.6 & 64.0 & 19.0 & 9.8 & 3.8 & 2.6 \\
\hline Bs $25-35$ & 0.2 & 0.4 & 70.6 & 15.2 & 8.4 & 4.6 & 0.6 \\
\hline Bsg 50-60 & 0.2 & 0.4 & 74.8 & 15.6 & 5.8 & 2.0 & 1.2 \\
\hline CBsg 90-100 & 2.2 & 3.2 & 47.8 & 24.8 & 13.5 & 6.4 & 2.1 \\
\hline
\end{tabular}

coarse and very coarse sand fraction. These features had higher informative value for differentiating horizons along PCA axis 1 . The second main component of PCA separated

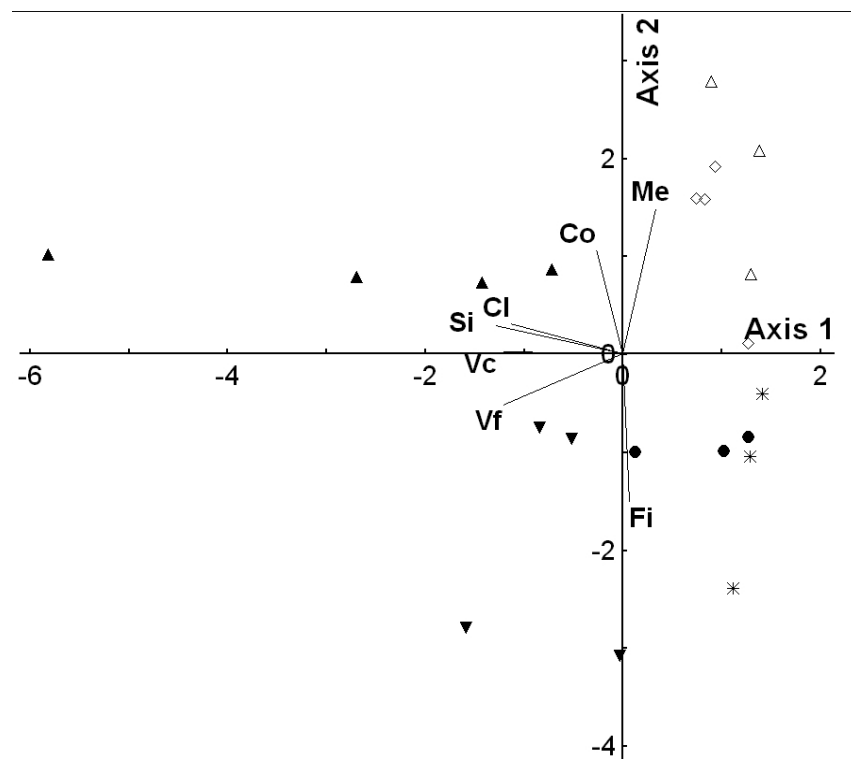

Fig. 5. Soil profile ordination by soil texture of the genetic horizons. (Factors: Vc - very coarse sand, Co - coarse sand, Me - medium sand, Fi fine sand, Vf - very fine sand, Si - silt, Cl - clay. Plot: 1 - Mia Sea, 2 Limnea Sea, 3 - Litorina Sea, 4 - drained lakebed, 5 - Baltic Ice Lake, 6 Northern Kursa Upland).

soils with medium and fine sand as the main fraction. Fine sand was typical for soils of the drained lakebed, Baltic Ice Lake and sea coast accumulation zone. Therefore, the fine (very fine sand, silt, clay) and coarse (very coarse and coarse sand) fraction proportions in the soil genetic horizons were mainly responsible for the differentiation of soil profiles. Significant positive correlations were also detected between coarse sand and medium sand; very coarse sand clay; very coarse sand - clay; very fine sand - silt; silt very coarse sand; very fine sand - very coarse sand; and silt - clay $\left(0.47 \leq \mathrm{r} \leq 0.82 \alpha_{0.05}\right)$.

C and N. The results showed that the organic soil layer accumulated a considerable amount of organic carbon and biologically inactive total nitrogen (Table 7). This soil layer in the catchment area, especially in the older land zones, consisted of moss of different degrees of decomposition. Its proportion of the total litter mass was more than $80 \%$. The

Table 7

CHEMICAL CHARACTERISTICS OF THE STUDIED SOILS IN RESEARCH PLOTS ( $\mathrm{n}=6$ ) IN THE LAKE ENGURE CATCHMENT AREA

\begin{tabular}{|c|c|c|c|c|c|c|c|c|c|}
\hline \multicolumn{2}{|c|}{ Horizon } & \multirow{2}{*}{$\begin{array}{l}\mathrm{pH}_{\mathrm{KCl}} \\
75 \pm 0.12\end{array}$} & \multirow{2}{*}{$\begin{array}{c}\begin{array}{c}\text { Hydrolytic } \\
\text { acidity, } \\
\text { mgekv/100g }\end{array} \\
109.82 \pm 18.07\end{array}$} & \multirow{2}{*}{$\begin{array}{c}\text { Base } \\
\text { saturation, } \% \\
13.67 \pm 2.33\end{array}$} & \multirow{2}{*}{$\frac{\mathrm{C}_{\text {org }}, \mathrm{g} / \mathrm{kg}}{13.52 \pm 31.03}$} & \multirow{2}{*}{$\begin{array}{c}\mathrm{N}_{\text {tot }}, \mathrm{g} / \mathrm{kg} \\
10.25 \pm 0.94\end{array}$} & \multirow{2}{*}{$\begin{array}{c}\mathrm{Ca}, \mathrm{mg} / \mathrm{kg} \\
2482.1 \pm 419.9\end{array}$} & \multirow{2}{*}{$\begin{array}{c}\mathrm{Fe}, \mathrm{mg} / \mathrm{kg} \\
337.5 \pm 59.5\end{array}$} & \multirow{2}{*}{$\begin{array}{c}\mathrm{Mn}, \mathrm{mg} / \mathrm{kg} \\
33.30 \pm 16.10\end{array}$} \\
\hline $\mathrm{O}$ & Mean & & & & & & & & \\
\hline & Range & $2.3-3.2$ & $60.0-160.7$ & $4-19$ & $313.2-508.2$ & $7.53-13.36$ & $1299-4239$ & $137-482$ & $1.60-107.80$ \\
\hline \multirow[t]{2}{*}{$\mathrm{E}$} & Mean & $3.82 \pm 0.14 \mathrm{a}$ & $2.32 \pm 0.59 a$ & $12.83 \pm 7.66 \mathrm{a}$ & $5.28 \pm 1.37 \mathrm{a}$ & $0.17 \pm 0.04 \mathrm{a}$ & $31.28 \pm 8.88 \mathrm{a}$ & $155.8 \pm 101.8 \mathrm{a}$ & $0.37 \pm 0.15 \mathrm{a}$ \\
\hline & Range & $3.3-4.2$ & $0.7-4.1$ & $1-50$ & $1.8-10.3$ & $0.09-0.33$ & $6.0-57.6$ & $20-662$ & $0.08-1.04$ \\
\hline \multirow[t]{2}{*}{ B } & Mean & $4.62 \pm 0.10 b$ & $1.72 \pm 0.49 \mathrm{a}$ & $5.33 \pm 1.41 \mathrm{a}$ & $3.82 \pm 0.93 a$ & $0.12 \pm 0.04 \mathrm{a}$ & $43.17 \pm 15.11 \mathrm{a}$ & $572.2 \pm 290.7 b$ & $1.10 \pm 0.46 a$ \\
\hline & Range & $4.4-5.1$ & $0.3-3.4$ & $2-10$ & $1.7-7.7$ & $0.02-0.21$ & $7.0-109.0$ & $77-1729$ & $0.30-2.79$ \\
\hline \multirow[t]{2}{*}{$\mathrm{C}$} & Mean & $4.85 \pm 0.16 b$ & $0.57 \pm 0.10 b$ & $16.33 \pm 3.33 b$ & $2.27 \pm 0.61 \mathrm{a}$ & $0.06 \pm 0.01 b$ & $73.82 \pm 23.93 a$ & $222.8 \pm 129.6 \mathrm{c}$ & $1.84 \pm 0.82 \mathrm{a}$ \\
\hline & Range & $4.5-5.4$ & $0.3-1.0$ & $6-29$ & $1.1-5.1$ & $0.02-0.10$ & $26.0-186.5$ & $45-857$ & $0.30-4.90$ \\
\hline
\end{tabular}

$\mathrm{n}$ - number of analyzed soil samples; SE - standard error; means annotated with different letters were significantly different (t-test, $P<0.05)$ from the upper mineral soil horizon. 
organic soil layer from the younger land zones, as well as from the pine stands of the coastal accumulation zone of the Baltic Sea (plots 1,4) contained higher proportions $(10-40 \%)$ of grasses and sword grasses, but lower content of organic carbon and $\mathrm{N}_{\text {tot }}$. Up to $10 \%$ of the total organic soil layer mass consisted of living and dead roots, as well as needle mass.

Soil acidity and base saturation. In general, the organic soil layer of the oligomesic pine forests could be characterized as comparatively homogenous by the content of base saturation and acidity (Table 7), but soil podsolisation processes were observed in mineral horizons. Lower hydrolytic acidity in the organic soil layer and mineral horizons was mainly found in the younger dry land zones (plots 1,4) in comparison with the soils of the older dry land zones.

Fe and Mn. The results of Fe and Mn content showed a higher content of $\mathrm{Fe}$ in the illuvial and parent horizon of the Baltic Ice Lake and Northern Kursa Upland soils, where gleying was less intensive and the main soil process was podsolisation. In general, a higher content of Mn was found in the organic soil layer and eluvial horizon of younger and wetter soils of the drained lakebed and the sea coast accumulation zone. The PCA of soil horizons revealed relatively good differentiation of soil plots according to their land age zone using results of Fe, Mn as well as soil acidity (Fig. 6). A positive correlation was identified between Fe content and very fine sand, and $\mathrm{Fe}$ and $\mathrm{Mn}$ content with silt and clay particles $\left(0.46 \leq \mathrm{r} \leq 0.78 \alpha_{0.05}\right)$.

Microelements - heavy metals. In total, the highest concentrations of microelements or heavy metals were found in the organic soil layer (Table 8). The detected average element content in the soil mineral layers did not significantly differ between the soil layers. The highest content of the three studied heavy metals $(\mathrm{Cd}, \mathrm{Zn}$, and $\mathrm{Cu})$ was found in the organic soil layer of the pine stand in the Limnea Sea zone (plot 2 located $\sim 150 \mathrm{~m}$ from the Jūrmala-Kolka road),

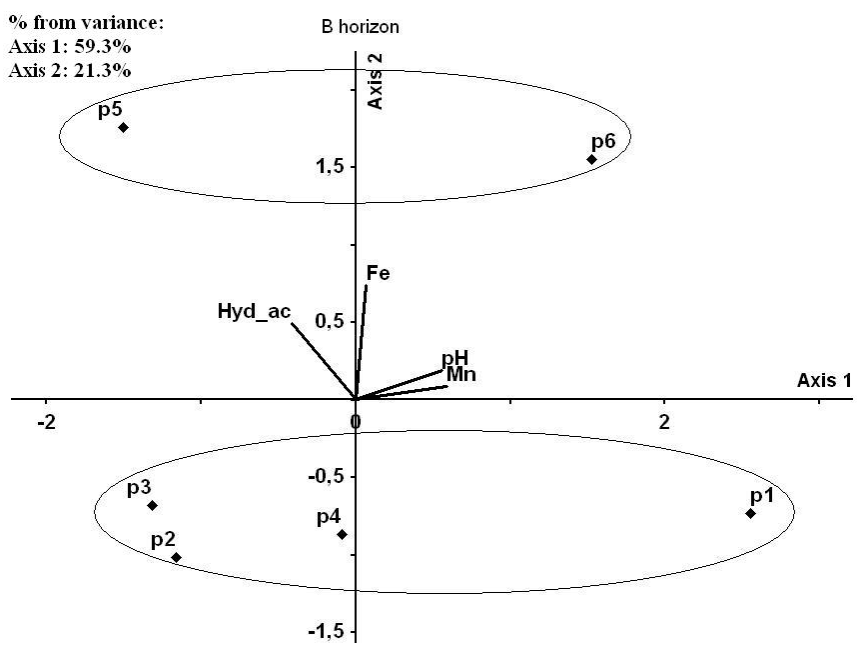

Fig. 6. Soil profile ordination by $\mathrm{Fe}$, Mn content and acidity in B horizon. (Factors: Hyd_ac - hydrolytic acidity, $\mathrm{pH}$ - soil reaction in $1 \mathrm{M} \mathrm{KCl}$. Plots: 1 - Mia sea, 2 - Limnea Sea, 3 - Littorina Sea, 4 - drained lakebed, 5 - Baltic Ice Lake, 6 - Northern Kursa Upland).
Table 8

HEAVY METAL CONTENT (MG/KG) OF THE STUDIED SOILS IN THE RESEARCH PLOTS ( $n=6)$ IN THE LAKE ENGURE CATCHMENT AREA

\begin{tabular}{|c|c|c|c|c|c|c|}
\hline \multicolumn{2}{|c|}{ Horizon } & $\mathrm{Pb}$ & $\mathrm{Cd}$ & $\mathrm{Zn}$ & $\mathrm{Cu}$ & $\mathrm{Ni}$ \\
\hline \multirow[t]{2}{*}{$\mathrm{O}$} & Mean & $18.44 \pm 4.21$ & $\begin{array}{c}0.199 \pm \\
0.050\end{array}$ & $24.34 \pm 6.10$ & $2.59 \pm 0.33$ & $1.11 \pm 0.17$ \\
\hline & Range & $3.20-28.16$ & $\begin{array}{r}0.11- \\
0.44\end{array}$ & $\begin{array}{c}15.59- \\
54.65\end{array}$ & $1.89-4.12$ & $0.50-1.63$ \\
\hline \multirow[t]{2}{*}{ E } & Mean & $1.10 \pm 0.27 \mathrm{a}$ & $\begin{array}{c}0.004 \pm \\
0.001 \mathrm{a}\end{array}$ & $0.51 \pm 0.09 a$ & $0.20 \pm 0.03 a$ & $0.03 \pm 0.01 \mathrm{a}$ \\
\hline & Range & $0.59-2.37$ & $\begin{array}{c}0.002- \\
0.009\end{array}$ & $0.20-0.80$ & $0.11-0.25$ & $0.02-0.04$ \\
\hline \multirow[t]{2}{*}{ B } & Mean & $0.87 \pm 0.20 \mathrm{a}$ & $\begin{array}{c}0.005 \pm \\
0.002 \mathrm{a}\end{array}$ & $0.95 \pm 0.40 \mathrm{a}$ & $0.31 \pm 0.07 \mathrm{a}$ & $0.12 \pm 0.06 b$ \\
\hline & Range & $0.46-1.57$ & $\begin{array}{c}0.002- \\
0.010\end{array}$ & $0.36-2.93$ & $0.09-0.50$ & $0.02-0.40$ \\
\hline \multirow[t]{2}{*}{$\mathrm{C}$} & Mean & $0.35 \pm 0.15 b$ & $\begin{array}{c}0.003 \pm \\
0.001 \mathrm{a}\end{array}$ & $0.36 \pm 0.08 b$ & $0.19 \pm 0.05 \mathrm{a}$ & $0.06 \pm 0.03 b$ \\
\hline & Range & $0.11-1.07$ & $\begin{array}{c}0.002- \\
0.006\end{array}$ & $0.14-0.70$ & $0.10-0.39$ & $0.02-0.22$ \\
\hline
\end{tabular}

$\mathrm{n}$ - number of analysed soil samples; SE - standard error; means annotated with different letters were significantly different (t-test, $P<0.05$ ) from the upper mineral soil horizon.

and the maximum $\mathrm{Pb}$ and $\mathrm{Ni}$ content in plot 3 or the Littorina Sea zone. There was a tendency for $\mathrm{Pb}$ content in the soil mineral horizons to be higher in soils with a higher content of organic matter, as well as with a higher proportion of silt and clay $\left(r=0.64 ; r=0.61 ; r=0.70 \alpha_{0.05}\right.$, respectively), e.g., in the Northern Kursa Upland and Baltic Ice Lake. There was also a significant $\left(\alpha_{0.05}\right)$ positive correlation between $\mathrm{Ni}, \mathrm{Cu}$ content and silt content in the mineral soil samples $\left(\mathrm{r}_{\mathrm{Ni}}=0.64 ; \mathrm{r}_{\mathrm{Cu}}=0.57\right)$, as well as $\mathrm{Ni}$ and very fine sand $(r=0.47)$. The results revealed a close correlation between the element content in the soil genetic horizons (profile): $0.55 \leq \mathrm{r} \leq 0.98, \mathrm{n}=27, \alpha_{0.05}$.

\section{DISCUSSION}

Soil. The research results of the Lake Engure catchment area revealed several tendencies and features of the soil and plant characteristics of dry pine forests.

Forest litter accumulation on soils in forest stands occurs every year. Decomposition and mineralisation intensity depends on its composition, trophic level of the habitat, moisture conditions, and other environmental factors. In boreal pine forests the decomposition of organic matter occurs slowly, and more humus is formed. In Latvia, it is $5-6 \mathrm{~cm}$ thick in dry pine forests, but in periodically wetter oligotrophic pine forests with a higher proportion of Vaccinium vitis-idea and accompanying species in the field layer, the O horizon is 10-30 cm (Bušs, 1981). The average depth of the organic soil layer of the oligotrophic pine forests in the Lake Engure catchment area was in this range. In general, the $\mathrm{C} / \mathrm{N}$ ratio in the organic soil layer was larger than 25 , indicating the slow mineralization of organic matter and a low 
biologically active N content (Дюшофур, 1970; Degorski, 1998; Lindross et al., 2011).

The oligomesic pine forests of the Lake Engure catchment area, which are mainly located in the Piejūras (Maritime) Lowland with higher groundwater levels, therefore with higher habitat humidity, are ecosystem examples of more southerly boreal forests. Gleying is a typical feature of boreal forest soils. It is affected by several factors: periodical or stable, stagnant or flowing humidity oversaturation, fermentation of organic matter, and anaerobic conditions, which promote formation of specific microflora (Зейдельман, 2009). Development of gleying in the study plots could be also promoted by the thick organic or litter layer (in some plots up to $15 \mathrm{~cm}$ thick), which probably prevent the soil from drying during summer. Gleying signs were found in all soil profiles, but formation of a stable gley horizon was not observed. Iron eluviation from the soil profile was found, which is a typical feature of the gleying process (Высоцкій, 1905; Zaidelman and Nikuforova, 1997), as well as mechanical eluviation of fine particles (silt and clay) or lessivage.

To determine the heavy metal or micronutrient status in the Lake Engure catchment area, $\mathrm{Pb}, \mathrm{Cd}, \mathrm{Cu}, \mathrm{Ni}$ and $\mathrm{Zn}$ concentrations in the soil samples were estimated. These elements are heavy metals which are mainly derived from human activities; therefore the concentration of these metals is an indicator of the degree of environment pollution. In general, the observed concentrations of $\mathrm{Pb}$ in our study could be characterized as elevated in comparison with the regional forest monitoring data for Vacciniosa and Myrtillosa, where the concentration of $\mathrm{Pb}$ in incinerated $\mathrm{O}$ horizon samples was around 4.4-5.1 mg/kg (Laiviņš et al., 1993). However, these levels were lower compared to the average concentration of $\mathrm{Pb}$ in mineral soils of Latvia using $1 \mathrm{M} \mathrm{HCl}$ extract (10-14 mg/kg) (Filipovičs, 1991; Upītis and Riṇkis, 1992). The concentrations of $\mathrm{Zn}$ were generally of the same level, but were higher in some plots than in those reported by Peive and Ivanova (Пейве и Иванова, 1956) in the forest topsoil organic layer (up to $26.0 \mathrm{mg} / \mathrm{kg}, 1 \mathrm{M} \mathrm{HCl}$ extract), and lower in mineral horizons in comparison to the sod heavy podzolic soils with $\mathrm{pH}$ less than $5.0-2.6-11.0$ $\mathrm{mg} / \mathrm{kg}$, as well as mineral soils in the Riga district: $1.5-41.0$ $\mathrm{mg} / \mathrm{l}$ (Riņ,is and Ramane, 1989). The slightly increased Pb and $\mathrm{Zn}$ content in the organic soil layer could be due to atmospheric deposition due to anthropogenic activities such as combustion of fossil fuels, transport, which lead to the emission of heavy metals and the accumulation of them in ecosystems (Kabata-Pendias and Pendias, 2001; He et al., 2005).

The obtained range of $\mathrm{Cu}$ concentrations in mineral horizons corresponded well with the levels of $\mathrm{Cu}$ detected for heavy podzolic agricultural soils $(0.5-0.8 \mathrm{mg} / \mathrm{kg})$ using $1 \mathrm{M}$ $\mathrm{HCl}$ extract (Peive, 1953), and for the sod podzolic sandy soils (0.6-0.9 mg/kg) (Liepiņš, 1979), but lower compared to mineral soils in the Riga and Ventspils districts (0.9-6.6 $\mathrm{mg} / \mathrm{l}$ and 1.0-2.6 mg/l) using the same extract (Riņkis and Ramane, 1989).
$\mathrm{Cd}$ and Ni concentration in the mineral horizons of pine forests was lower in comparison with results using $1 \mathrm{M} \mathrm{HCl}$ soil extract in mineral soil of Riga (Cekstere and Osvalde, 2013) and the roadside soils in Latvia (Osvalde, 1996). In Latvia, according to Vucāns et al. (1999), Cd concentration in mineral soil samples extracted in the aqua-regime, which characterizes the pseudototal content of elements in the soil, is about $0.07-0.71 \mathrm{mg} / \mathrm{kg}$, but in digested samples of litter layer in Vacciniosa and Myrtillosa forests - Cd $0.1 \mathrm{mg} / \mathrm{kg}$, $\mathrm{Ni}$ - 3.7-5.3 mg/kg (Laiviņš et al., 1993). However, it is difficult to objectively compare these data with our findings.

In general, the detected concentrations of five heavy metals were 2-4 times lower compared with the findings of Brūmelis et al. (2002) on total element concentrations in the organic soil layer of pine forests in Latvia, mainly due to methodological differences in laboratory analysis. The correlations between the heavy metal concentrations in the Lake Engure catchment area soil indicate a common source of origin for these metals. The positive correlations between the heavy metals in the Lake Engure catchment area corresponded well with the correlations between $\mathrm{Cu}, \mathrm{Cd}, \mathrm{Pb}$, and $\mathrm{Zn}$ found in the $\mathrm{O}$ horizon of pine forests in Latvia (Brūmelis et al., 2002).

Our results indicated that the concentration of microelements or heavy metals in the sandy soil horizons of pine stands depended significantly on the content of silt and clay particles. Similar observations on the relationship of soil texture with concentration of chemical elements have also been found in other studies of forest (Gilucis, 2007; Tērauda, 2008; Kasparinskis, 2012; etc.) and agricultural soils (Liepiņš, 1978) in Latvia.

The concentrations of elements in the organic forest layer could be affected by natural factors, e.g., forest stands, biological cycling of elements, variable mixture of decaying plant material, mixing with mineral horizons by soil invertebrates, losses by leaching, soil $\mathrm{pH}$, the moisture regime and drainage, competition between elements for absorbtion sites (Steinnes and Njastad, 1995; Brumelis et al., 2002; Kasparinskis, 2012).

Generally, a slightly higher content of elements was found in the illuvial B horizon, especially in the Northern Kursa Upland and Baltic Ice Lake land zone, as well as in the individual, more gleyic horizons of the drained lakebed, probably due to a longer period of soil formation. In general, soils of pine stands growing near the sea had the lowest content of microelements / heavy metals, as well as silt and clay particles.

Pine stands species composition and environmental factors. The research results revealed that the narrow accumulation coastal zone had a distinctive pine stand species composition with the Chimaphila umbellate group species Pyrola chlorantha, Chimaphila umbellate, Thymus serphyllum, Dianthus arenaria. Additionally, often other xerofitic pine forest indicator species (Geranium sanguineum, Pulsa- 
tilla pratensis, and Convallaria majalis) were found in similar habitats outside the study plot. In comparison with other pine stands, a considerably larger cover of Carex arenaria group species, but a smaller cover of Vaccinium vitis-idaea and Vaccinium myrtillus group species were found in the accumulative coastal zone. Significantly, no boreal indicator species such as from the Ledum palustre group were found in the pine stands of the accumulative coastal zone.

Analysis of environmental conditions using Ellenberg's indicator values showed that soil acidity was the distinguishing factor, as well as habitats along the sea, which were warmer and with higher penetration of light (Fig. 7).

Chimaphila umbellate group species are indicator species of submeridional xerophilous pine forests (steppe pine forests) (Oberdorfer, 1992; Wallnöfer, 1993; etc.). Xerophilous pine forest community fragments are also found in temperate zone habitats, which are warm and usually also contain carbonates (Meusel, 1952; Fukarek, 1961; Krausch, 1962; Bjørndalen, 1985). Such habitats are common on esker or ridge relief forms, in river valleys and sometimes also in sandy sea coast forests.

Based on the high proportion of Chimaphila umbellata and Carex arenaria group species in the coastal pine stand field layer, as well as the overall environmental conditions (increased Ca content in soil, higher continentality of local climate, as well as constant disturbance (accumulation of sand and wind erosion), in our opinion, the pine stand communi-

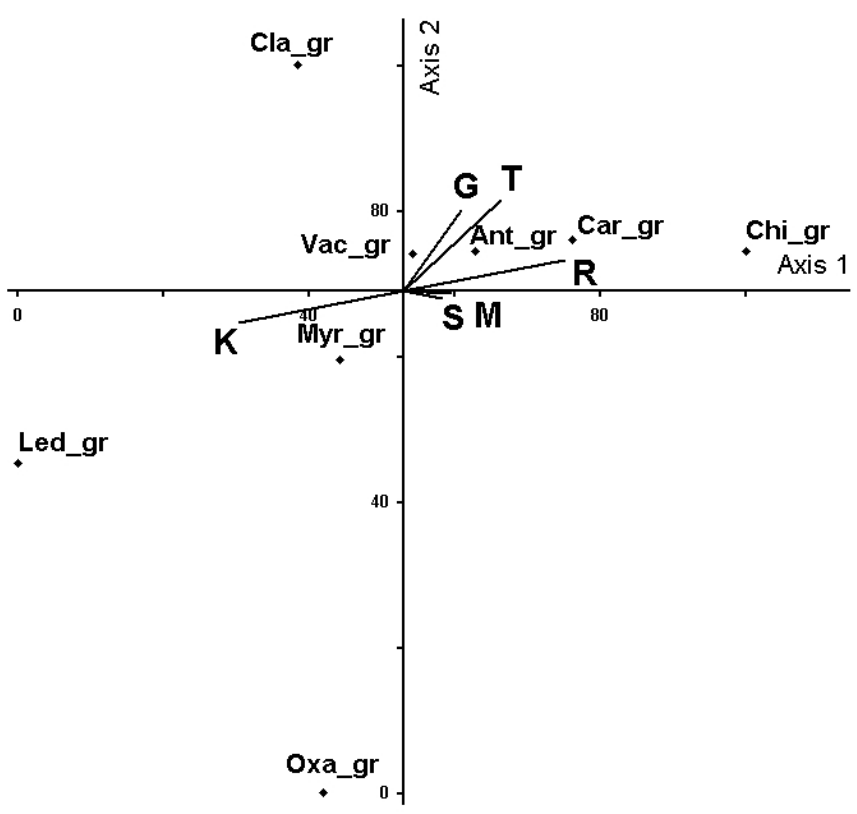

Fig. 7. Plant species sociological group ordination by DCA. (Plots: $1-\mathrm{Mia}$ Sea, 2 - Limnea Sea, 3 - Littorina Sea, 4 - drained lakebed, 5 - Baltic Ice Lake, 6 - Northern Kursa Upland. Sociological groups: Cla_gr. - Cladina, Vac_gr. - Vaccinium vitis-idaea, Myr_gr. - Vaccinium myrtillus, Oxa_gr. - Oxalis acetosella, Led_gr. - Ledum palustris, Ant_gr. Antoxanthum odoratum, Car_gr. - Carex arenaria, Chi_gr. - Chimaphila umbellatu. Ellenberg's factors: G - light, T - temperature, K continentality, $\mathrm{M}$ - moisture, $\mathrm{R}$ - reaction, $\mathrm{S}$ - nitrogen. ties of the sea sandy coastal zone could be classified as vegetation units of submeridional xerophilous pine forest classes Pulsatillo-Pinetea.

In comparison with the pine stands of the drainage basin inland, where low shrub species (Vaccinium, Ledum etc.) are dominant in the field layer and belong to the Vaccinio-Piceetea plant community class, the existence period of xerophilous pine stands is considerably shorter. Pine as the dominant species in the coastal zone pine stands can probably exist for several generations (pine trees in young growth in canopy gaps, as well as trees of various ages in stands), thereby maintaining constant species composition for hundreds of years. As the intensity of sea coastal processes (wind and wave acitivities) and carbonate leaching from soil decreases, low shrubs like Vaccinium vitis-idaea, Vaccinium myrtillus and Calluna vulgaris can assume the dominant role in the field layer, and the xerophilous pine stands could transform into boreo-atlantic pine forest communities.

It was typical that Picea abies was not found in the pine stands of younger dry land stages - the drained lakebed and Mia and Limnea Sea dryland zone stands. Young spruce were found in the pine stands of the Littorina Sea dryland zone, but in the oligomesic pine stands of the Baltic Ice Lake zone and Northern Kursa Upland spruce was found at the height of the tree layer. It was also typical that in the older dry land zones Betula pendula and Quercus robur were also observed in the sapling layer and in admixture with pine trees. The forest cadastre data also indicate diversification of stand species composition in the Lake Engure catchment area with the distance from the sea (Laiviňš et al., 2013).

Higher proportions of grasses and sword grasses in the field layer of the pine stands of the drained lakebed and sea coastal area were associated with the comparatively low forest age, and reflected expansion of sword grasses (graminification process) due to nitrogen deposition in the ecosystem (Kuhn et al. 1987; Falkengren-Gerup, 1989; Tamm, 1991; Laiviňš, 1998; van Dobben et al. 1999; Laiviňš et al.; 2007; Remke et al.; 2009; Nielsen et al. 2011).

Productivity of pine stands. The results showed that there were remarkable differences in both the actual and the potential productivity of the oligomesic pine stands of the dry land age zones of the Lake Engure catchment area. Differences in the current stock volume can be explained by difference in stand age (the largest difference between average stand age in plots was 30 years). Currently, pre-mature pine stands in the drained lakebed and Littorina Sea accumulation zone were the most productive. Also at 100 years of age, the predicted stock volume of stands in these zones is $600-700 \mathrm{~m}^{3} / \mathrm{ha}$. This is in good agreement with the volume of highly productive pine stands in Western Latvia at a mature stand age (Zālītis and Jansons, 2009). Calculating the prospective stock volume at an age of 100 years based on the retrospective accumulation of stock volume in stands, which relatively objectively estimates productivity, the dif- 
ferences in stand stock volume still exist. This means that environmental factors and especially local habitat factors, both biotic and abiotic, have important roles in the productivity of pine forests. According to a study of pine forests near Lake Engure by Dauškane and Elferts (2011), yearly and growing period precipitation, and yearly and dormantperiod temperature have a positive influence on Scots pine growth on dry, well-drained, podzolic sandy soils, corresponding to the Vacciniosa site type.

Therefore, the relationships between the stand parameters in the plot area (tree number, average diameter of stem, average height, stand basal area, potential stock volume at age 100 years) and texture of mineral topsoil $(50 \mathrm{~cm}$ depth, E and $\mathrm{B}$ horizons), as well as the plant sociological group proportion in the field layer, composition of organic soil layer and Ellenberg's indicator values were studied using DCA methods. As was expected, the pine stands were divided into two groups according to stand parameters and potential stock volume: more productive pine stands of the drained lakebed and Littorina Sea (sea coastal pine stands were also similar to this group in the ordination space) and less productive pine stands of the Limnea Sea, Baltic Ice Lake and Northern Kursa Upland. Stem diameter and tree height were the most significant distinguishing parameters: Kendal's correlation coefficient of the first axis with stem diameter was 0.867 and with tree height -0.600 .

Ordination of the stand parameters by soil texture parameters revealed that more productive stands were positively associated with fine sand proportion, and less productive stands with medium, coarse and very coarse sand (Fig. 8A). In comparison with coarse and very coarse sand, fine sand adsorbs a higher amount of plant nutrients which influences tree productivity.

Field layer species (in this case - plant sociological groups) and organic soil layer composition are important indicators of habitat fertility. The more productive drained lakebed and Littorina Sea zone stands had a higher amount of grass, sword grass, as well as proportion of mesophytic herbs. Whereas low shrubs of poor boreoatlantic sandy pine forests were edificator species of less productive inland pine stands, as well as the Limnea Sea dune zone field layer (Fig. 8B). The litter layer of more productive pine stands had a higher amount of grass fraction and biologically active nitrogen, while the litter layer of less productive stands had moss and low shrub roots, and increased humus formation was observed (Fig. 8C, D). Probably, a small amount of grass admixture in the field layer can promote mineralization of organic matter and eutrophication processes in topsoil, which can facilitate pine growth.

In general, the structure of pine stands of the Lake Engure catchment area is not strongly determined by the dry land age zones, and varies due to impact of local habitat conditions and disturbances. However, some distinctive features of pine stands in the Bērzciems-Vandzene transect, which crossed six dry land zones formed in different periods of the Holocene, should be noted:
A

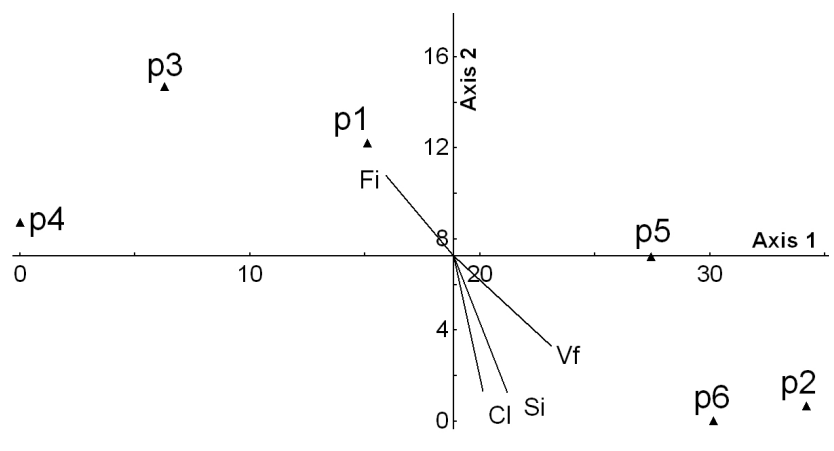

B

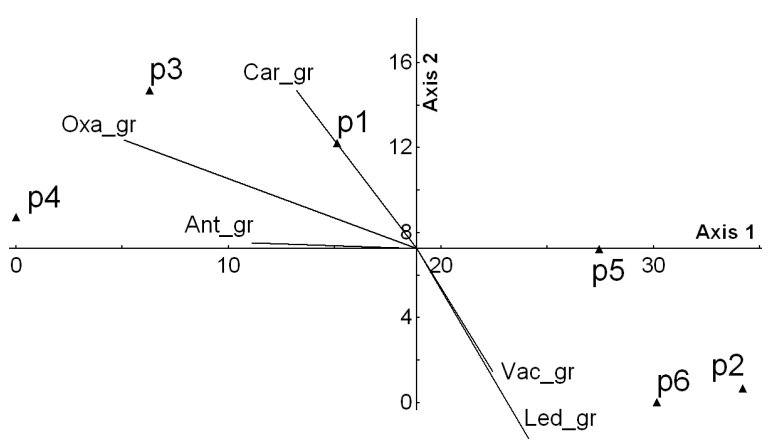

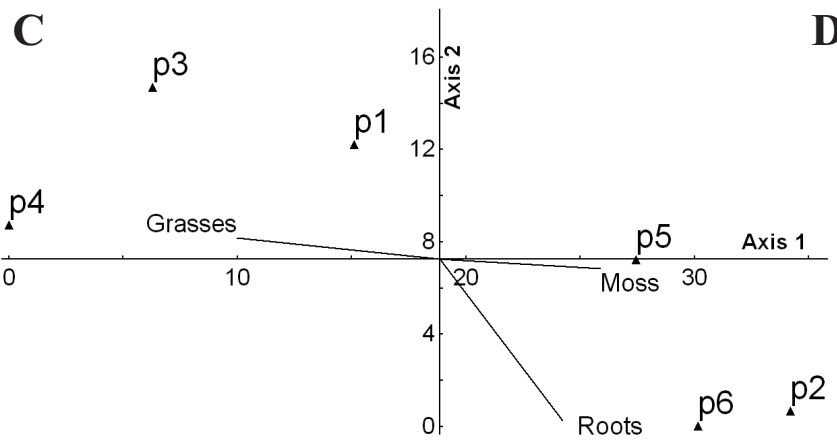

D

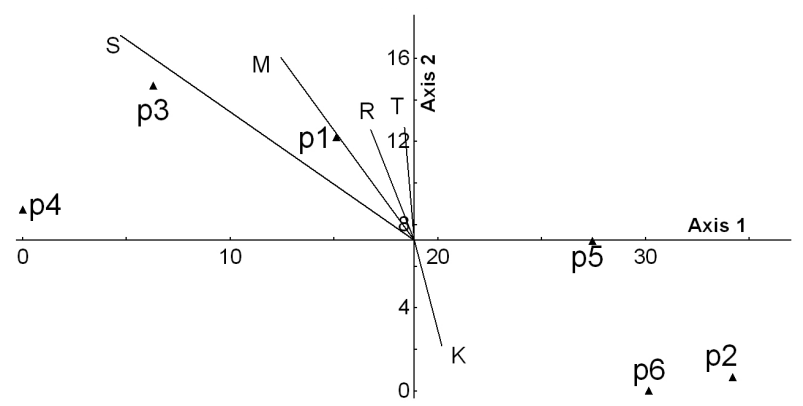

Fig. 8. Ordination of plots according to stand parameters with DCA. (Plots: 1 - Mia Sea, 2 - Limnea Sea, 3 - Littorina Sea, 4 - drained lakebed, 5 - Baltic Ice Lake, 6 - Northern Kursa Upland. A: Soil texture classes: Fi - fine sand, Me - medium sand, Co - coarse sand, Vc - very coarse sand, Vf - very fine sand. B: Plant species sociological groups: Ant_gr. - Antoxanthum odoratum group, Car_gr. - Carex arenaria group, Chi_gr. - Chimaphila umbellata group, Oxa_gr. - Oxalis acetosella group, Led_gr. - Ledum palustre group, Vac_gr. - Vaccinium vitis-idaea group. C: Litter composition: grasses, moss, roots. D: Ellenberg's indicator values: $\mathrm{L}$ - light, $\mathrm{T}$ - temperature, $\mathrm{K}$ - continentality, $\mathrm{F}$ - moisture, $\mathrm{R}$ - reaction, $\mathrm{N}$ - nitrogen. 
(i) Pine stands of the sea coastal zone (Mia Sea dry land zone), which have formed over a period of several hundreds of years under continuous accumulation of sea sediment and strong wind effect, differed by species composition from the forests in the older inland zones and belonged to the submeridional xerophilous pine forest Pulsatillo-Pinetea community class. Xerophilous coastal pine stands are pioneer communities of boreoatlantic conifer forest (Vaccinio-Piceetea) in context of stand development in the longer period (hundreds and thousands of years).

(ii) Grasses and sword grasses were typical in the pine stand field layer of younger dry land zones (the drained lakebed and Mia Sea zone). The role of low shrubs in the field layer will increase due to pine remaining as the dominant species over a longer period and habitat stabilisation.

(iii) Soils of the dry oligomesic pine stands of the Lake Engure catchment area typically had gleying features in soil genetic horizons, and active iron and manganese leaching from the soil profile. Signs of podsolisation (ortsand horizon) were only clearly distinguishable in the soil profile morphology of older dry land zones (Baltic Ice Lake and Northern Kursa Upland).

(iv) The most productive pine stands were located in the youngest dry land zone - the drained lakebed zone, where currently, obviously, the first generation pine forest had developed. Pine stands with lower productivity occurred in older zones - the Baltic Ice Lake sediment zone and Northern Kursa Upland, where the forests had probably been present for thousands of years. It is significant that pine stands with a higher amount of stock volume were poorer with species in the field layer and only one species (pine) formed the tree layer. The stands with lower stock volume had a higher number of species in the field layer, and there was admixture of other species with pine in the tree layer.

Mutual interaction of natural, social and human processes in the dry land zones of different age are basic spatial structures of a conceptual model for investigation of socioecological processes in the Lake Engure ecoregion (Melecis, 2011; Melecis and Klaviņš, 2013; Leitis, 2013). The socioecological research materials and theoretical approaches utilised in this study of the Lake Engure catchment area could be expanded to a wider geographical region Kurzeme - as the natural and social conditions and development of dry land age zones of the Lake Engure ecoregion, reflect the environmental history of Western Latvia in the Holocene in general.

\section{ACKNOWLEDGEMENTS}

The research was carried out in the framework of the national cooperative project No. 10.0004 financed by the Latvian Council of Science. The authors are very grateful to D. Rungíis for English corrections.

\section{REFERENCES}

Ābolin,a, A. (2001). Latvijas sūnu saraksts [List of bryophytes of Latvia]. Latvijas Vegetācija, 3, 47-87 (in Latvian).

Bjørndalen, J. E. (1985). Some synchorological aspects of basiphilous pine forests in Fennoscandia. Vegetatio, 59, 211-224.

Brūmelis, G., Lapin,a, L., Nikodemus, O., Tabors, G. (2002). Use of the O horizon of forest soils in monitoring metal deposition in Latvia. Water Air Soil Pollut., 135, 291-309.

Buharts, S. (1935). Kvartārie veidojumi Talsu novadā [Quarternary formations in Talsi region]. Enciklopēdisks rakstu krājums Talsu novads. Rīga: Talsu un Tukuma studentu biedrība,17.-50. 1pp. (in Latvian).

Bušs, K. (1981). Meža ekologiija un tipologija [Forest Ecology and Typology]. Rīga: Zinātne. 65 lpp. (in Latvian).

Cekstere, G., Osvalde, A. (2013). A study of chemical characteristics of soil in relation to street trees status in Riga (Latvia). Urban For. Urban Green., 12, 69-78.

Dauškane, I., Elferts, D. (2011). Influence of climate on Scots pine growth on dry and wet soils near Lake Engure in Latvia. Est. J. Ecol., 60 (3), 225-235.

Degorski M. (1998). Spatial and Vertical Distribution of Soil PhysicoChemical Properties and the Content of Heavy Metals in the Pedosphere in Poland. USDA Forest Service Gen. Tech. Rep. PSW-GTR-166, pp. 169-177.

Dierschke, H. (1994). Pflanzensoziologie. Stuttgart: Verlag Eugen Ulmer. $683 \mathrm{~S}$.

Eberhards, G. (2003). Latvijas jūras krasti [Latvian Coast of the Baltic Sea]. Latvijas Universitāte, Rīgā. 292 lpp. (in Latvian).

Eberhards, G., Saltupe, B. (2000). Geological history, relief, and deposits of the Lake Engures (Engure) area along the Baltic Sea. Proc. Latvian Acad. Sci. Section B, 54 (5/6), 141-147.

Eberhards, G., Lapinskis, J. (2008). Processes on the Latvian Coast of the Baltic Sea. Atlas. Rīga: LU Akademiskais apgāds. 63 pp.

Ellenberg, H., Weber, H.E., Düll, R., Wirth, V., Werner, E., Paulissen, D. (1992). Zeigerwerte von Pflanzen in Mitteleuropa. Göttingen: Verlag Erich Goltze KG. 258 S.

Falkengren-Gerup, U. (1990). Grasses on the increase. Acid Magazine, 9, 24-25.

Fiḷipovičs, J. (1991). Republikas augšņu radioaktivitāte un svina saturs tajās [Radioactivity of soils in the Republic and content of lead]. Ekspresinformācija , Ražība”, 10, 46-50 (in Latvian).

Fukarek, F. (1961). Die Vegetation des Darss und ihre Geschichte. Pflanzensoziologie, 12, XIII+321.

Gavrilova, G̦., Šulcs, V. (1999). Latvijas vaskulāro augu flora. Taksonu saraksts [Vascular Plant Flora in Latvia. List of Taxons]. Rīga. 136 lpp. (in Latvian).

Gilucis, A. (2007). Mikro- un makroelementu satura izplatības likumsakarības Latvijas augšnu virsējos horizontos [Relevance of Content and Distribution of Trace and Major Elements in the Latvian Topsoils]. Summary of Doctoral Thesis. Rīga: LU Akadēmiskais apgāds. 29 pp.

He, Z. L., Yang, X. E., Stoffellam, P. J. (2005). Trace elements in agroecosystems and impacts on the environment. J. Trace Elem. Med. Biol., 19, 125-140.

Hill, M. O. (1979). TWINSPAN. A FORTRAN Program for Arranging Multivariate Data in an Order Two Way Table by Classification of the Individuals and Attributes. Ecology and Systematics. New York: Cornell University Ithaca. $47 \mathrm{pp}$.

Kabata-Pendias, A., Pendias, H. (2001). Trace Elements in Soils and Plants. $3^{\text {rd }}$ edn. USA: CRC Press, Boca Raton. 436 pp.

Kārkliņ̌̌, A. (2008). Augsnes diagnostika un apraksts [Soil Diagnostic and Description]. Jelgava: Latvijas Lauksaimniecības Universitāte. 335 lpp. (in Latvian). 
Kasparinskis, R. (2012). Latvijas meža augšṇu daudzveidība un to ietekmējošie faktori [Diversity of Forest Soils and Its Influencing Factors in Latvia]. Doctoral Thesis. Rīga: LU Akadēmiskais apgāds. 154 pp.

Krausch, H.D. (1962). Der Sandnelken-Kiefernwald an seiner Westgrenze in Brandenburg. Mitteilungen der Floristisch-soziologischen Arbeitsgemeinschaften. Neue Folge, 9, 141-144.

Kuhn, N., Amiet, R., Hufscmidt, N. (1987). Veränderungen in der Waldvegetation des Schweiz infolge Nährstoffanreicherung aus der Atmosphäre. Allgemaine Forst- und Jagdzeitung, 158, 77-84.

Kurpniece, L., Latkovska, I., Apsīte, E. (2013). Engures ezera sateces baseina upju noteces ilgtermina izmaiṇas 20. un 21. gadsimtā [Long-term changes in the discharge channels in the Lake Engure river basin in the $20^{\text {th }}$ and $21^{\text {th }}$ centuries]. Grām.: Kḷavin̄š, M., Melecis, V. (eds.). Cilvēks un daba: Engures ekoreǵions (91.-106. 1pp.). Rīga: LU Akadēmiskais apgāds (in Latvian).

Laiviņš, M. (1998). Latvijas boreālo priežu mežu sinantropizācija un eitrofikācija [Synantrophisation and eutrophisation of Latvian boreal pine forests]. Latvijas Veǵetācija, 1, 1-137 (in Latvian).

Laiviņš, M., Bambe, B., Rūsiņa, S., Piliksere, D., Kreile, V. (2008). Augu sugu socioloğisko grupu ekoloǵija un ǵeogrāfija Latvijas skujkoku mežos [Ecology and geography of plant species sociological groups in conifer forests in Latvia]. Latvijas Lauksaimniecības Universitātes Raksti, 20, 1-21 (in Latvian).

Laivinš, M., Gavrilova, G., Medene, A. (2013). Veǵetācijas attīstība un struktūra Engures ezera sateces baseinā [The structure and development of vegetation in Lake Engure's river basin]. Grām.: Klaviņš, M., Melecis, V. (eds.). Cilvēks un daba: Engures ekoreǵions (174.-198. 1pp.). Rīga: LU Akadēmiskais apgāds (in Latvian).

Laiviņš, M., Rūsiņa, S., Frolova, M., Lyulko, I. (2007). Pine forest vegetation dynamics at ICP IM sites in Latvia. In: Kleemola, S., Forsius, M. (eds.). 16th Annual Report 2007. UNECE Convention on Long-range Transboundary Air Pollution. International Cooperative Programme on Integrated Monitoring of Air Pollution Effects on Ecosystems. The Finnish Environment, 26 (pp. 37-56). Helsinki: Finnish Environment Institute.

Laiviņš, M., Rūsiņa, S., Medene, A., Gavrilova, G., Āboliņa, A. (2012) Augāja stabilizācija Engures ezera sateces baseinā. I. Kalcifîtās augu sabiedribas [Stabilization of vegetation in catchment area of the Lake Engure. I. Calcareous plant communities]. Latvijas Veǵetācija, 23, 21-81 (in Latvian).

Laivin̄š, M., Sīpols, M., Riekstina, D. (1993). Reǵionālais meža monitorings Latvijā [Regional Forest Monitoring in Latvia]. Rīga. 149 lpp. (in Latvian).

Liepiņš, J. (1979). Vara satura izmaiņas lauksaimniecībā intensīvi izmantojamās augsnēs [Changes of copper content in heavy used soils in agriculture]. Padomju Latvijas Lauksaimniecība, 12, 17-19 (in Latvian).

Lindroos, A. J., Derome, J., Derome, K., Smolander A. (2011). The effect of Scots pine, Norway spruce and silver birch on the chemical composition of stand throughfall and upper soil percolation water in northern Finland. Boreal Env. Res., 16, 240-250.

McCune, B., Grace, J. B. (2002). Analysis of Ecological Communities. Oregon: MjM Software Design Glenden Beach. 300 pp.

McCune, B., Mefford, M. J. (1999). PC-ORD. Multivariate Analysis of Ecological Data, Version 4. Oregon: MjM Software Design.

Medene, A. (2012). Engures ezera sateces baseina mežu struktūra un dinamika [Structure and dynamic of forests of the Lake Engure river basin]. Latvijas Vegetācija, 23, 5-19 (in Latvian).

Meusel, H. (1952). Vegetationskundliche Studien über mitteleuropäische Waldgesellschaften III. Über einige Waldgesellschaften der Insel Rügen. Berichte der Deutschen Botanischen Gesellschaft, 64, 222-240.

Nielsen, K. E., Degn, H. J., Damgaard, Ch., Bruus, M., Nygaard, B. (2011). A native species with invasive behaviour in coastal dunes: Evidence for progressing decay and homogenization of habitat types. Ambio, 40, 819-823.
Oberdorfer, E. (1992). Klasse: Pulsatillo-Pinetea sylvestris. In: Oberdorfer (Hrg.) Süddeutsche Pflanzengesellschaft. Teil IV Wälder und Gebüsche. A. Textband (S. 33-41.). Jena, Stuttgart, New York: Gustav Fischer Verlag,

Osvalde, A. (1996). Heavy metals - Pb, Hg, Ni, V, Sn — in biological objects of Latvia, lowering of their toxicity by regulating plant nutrition. Summary of PhD Thesis. Riga: University of Latvia.

Peive, J. (1953). Mikroelementu — bora, vara un kobalta nozīme lauksaimniecībā [Significance of microelements, boron, copper and cobalt, in agriculture]. Augsne un Raža, 3, 5-19 (in Latvian).

Penēze, Z., Krūze, I., Medene, A. (2013). Ainavas Engures ezera sateces baseinā un tās ietekmējošie faktori [Landscapes in the Lake Engure river basin and their influential factors. Grām.: Kḷaviṇš, M., Melecis, V. (eds.) Cilvēks un daba: Engures ekoreǵgions (61.-90. 1pp.). Rīga: LU Akadēmiskais apgāds (in Latvian).

Piterāns, A. (2001). Latvijas kēerpju konspekts [Checklist of the lichens of Latvia]. Latvijas Veǵetācija, 3, 5-46 (in Latvian).

Remke, E., Brouwer E., Kooijman, A., Blindow, I., Esselink, H., Roelofs, J. G. V. (2009). Even low to medium nitrogen deposition impacts vegetation of dry, coastal dunes around the Baltic Sea. Environ. Pollut., 157, 792-800.

Riņkis, G., Ramane, H. (1989). Kā barojas augi [Plant Nutrition]. Rīga: Avots, 151 lpp.

Rūsina, S. (2007). Latvijas mezofìto un kserofīto zālāju daudzveidība un kontaktsabiedrības [Diversity and contact communities of mesophytic and xerophytic grasslands in Latvia]. Latvijas Vegetācija, 12, 1-366 (in Latvian).

Rūsiņa, S., Piliksere, D. (2005). Latvijas sausieṇu egḷu mežu augu sugu socioloǵiskās grupas [Plant species sociological groups of dry spruce forests in Latvia]. Latvijas Lauksaimniecības Universitātes Raksti, 14, 30-39 (in Latvian).

Rūsiṇa, S., Priede, A., Toča, L. (2013). Dabiskie zālāji Engures ezera sateces baseinā — izmirstošas ekosistēmas vai neapzināts resurss? [Natural grasslands in the Lake Engure river basin - dying ecosystems or unknown resources?] Grām.: Kḷaviņš, M., Melecis, V. (eds.). Cilvēks un daba: Engures ekoreǵions (199.-222. lpp.). Rīga: LU Akadēmiskais apgāds (in Latvian).

Sarma, P. (1948). Meža taksācija [Forest Inventory]. Rīga: LVI. 590 lpp. (in Latvian).

Skujāns, R., Mežals, G. (1964). Augšnu pētišana [Soil Research]. $2^{\text {nd }}$ ed. Rīga: Latvijas valsts izdevniecība. 348 lpp. (in Latvian).

Steinned, E., Njastad, O. (1995). Enrichment in the organic surface layer of natural soil: Identification of contributions from different sources. Analyst, 120, 1479-1483.

Strautnieks, I. Grīne, I. (2013). Engures ezera sateces baseina ǵeoloǵiskā uzbūve un reljefs: to nozīme zemes lietojumveida un apdzīvojuma struktūrā [The geological structure and relief of the Lake Engure river basin, their significance regarding land use and inhabitation structure]. Grām.: Klavinš, M., Melecis, V. (eds.). Cilvēks un daba: Engures ekoreǵions (29.-60. lpp.). Rīga: LU Akadēmiskais apgāds (in Latvian).

Strautnieks, I., Grīne, I. (2011). Lake Engures catchment area as an example for the interaction of natural condition, settlement pattern and economic activities. Proc. Latvian Acad. Sci. Sect. B, 65 (5/6), 117-126.

Tamm, C. O. (1991). Nitrogen in terretrial ecosystems: Question of productivity, vegetational changes and ecosystems stability. Ecol. Studies, 81, $1-115$

Tērauda, E. (2008). Ķīmisko vielu plūsmas Latvijas priežu mežu ekosistēmās [Flows of Chemical Substances in Latvian Pine Forests Ecosystems]. Doctoral Thesis. Rīga: LU Akadēmiskais apgāds. 123 pp.

Upītis, V., Riṇkis, G. (1992). Augsnes un augu piesārņojums ar svinu, tā kritēriji [Soil and plant pollution with lead, its criteria]. LZA Vēstis, 5, 49-53 (in Latvian).

Van Dobben, H. E., Ter Braak, C. J. E., Dirkse, G. M. (1999). Undergrowth as a biomonitor for deposition of nitrogn and acidity in pine forest. Forest Ecol. Manag., 114, 83-95. 
Vanmecheln, L., Groenemans, R., Van Rast, E. (1997). Forest soil condition in Europe. Results of a large-scale soil survey. 1997 Technical Report. Brussels, Geneva: EC, UN/ECE, Ministry of the Flemish Community. 259 pp.

Vucāns, A., Gemste, I., Līvmanis, J. (1999). Kadmija saturs Latvijas augsnēs un augos [Content of cadmium in soils and plants in Latvia]. Latvijas Lauksaimniecības Universitātes Raksti, 1, 85-93 (in Latvian).

Wallnöfer, S. (1993). Pulsatillo-Pinetea. In: Mucina, L., Grabherr, G., Wallnöfer, S. (Hrg.). Die Pflanzengesellscgaften Österreichs Bd. III (S. 237-243). Jena, Stuttgart, New York: Gustav Fischer Verlag.

Zaidelman, F. R., Nikiforova, A. S. (1997). On some general regularities of the formation and changes in properties of $\mathrm{Mn}$ and Fe concretions in soils of humid landscapes. Arch. Agr. Soil Sci., 41 (5), 367-382.

Zālītis, P., Jansons, J. (2009). Mērk̦tiecīgi izveidoto kokaudžu struktūra [Structure of Focused Established Stands]. Salaspils: Latvijas Valsts Mežzinātnes institūts Silava. 80 lpp. (in Latvian).

Zelčs V., Markots A. (2004). Deglaciation history of Latvia. In: Ehlers, J., Gibbard, P. L. (eds.). Quaterny galciations - extent and chronology. Part I: Europe (pp. 225-243). Elsevier.
Буш К. К., Аболинь А. А. (1968). Строение и изменение растительного покрова важнейших типов леса под влиянием осушения [Bush, K. K., Abolin, A. A. Composition and changes of vegetation of main forest types under impact of drainage]. В К. К. Буш (ред.). Вопросы гидролесомелиорации (с. 71-126). Рига: Зинатне (in Russian).

Высоцкій Г. Н. (1905). Глей [Visotsky, G. Gley]. Почвоведение, 7 (4), 291-327 (in Russian).

Дюшофур Ф. (1970). Основы почвоведения и эволюции почв [Duchaufour, P. Principles of Soil Science and Evolution]. Москва: Прогресс. 587 с. (in Russian).

Зейдельман Ф. Р. (2009). Генезис и экологические основы мелиорации почв и ландиафтов [Eidelman, F. R. Genesis and Ecological Base for Soil Melioration and Landscapes]. Москва: Книжный дом университет. 720 c. (in Russian).

Пейве Я. В., Иванова Н. Н. (1956). О содержании цинка в почвах Латвийской CCP [Peive, J. V., Ivanova, N. N. Zinc content in soils in the Latvian SSR]. В: Пейве, Я. В. (еd.), Микроэлементы в сельском хозяйстве и медицине (с. 479-484). Рига: Изд-во АН Латвийской ССР (in Russian).

Ринькис Г. Я., Рамане Х. К., Куницкая Т. А. (1987). Методы анализа почв и растений [Rin,kis, G., Ramane, H., Kunicka, T. Methods of Soil and Plant Analysis]. Рига: Зинатне. 174 с. (in Russian).

Received 3 February 2014

\section{OLIGOMEZOTROFO PRIEŽU MEŽU STRUKTŪRA UN DINAMIKA ENGURES EZERA SATECES BASEINA SAUSZEMES ZONĀS}

Engures ezera sateces baseina sešās sauszemes vecuma zonās (nosusinātās ezerdobes, Mia, Limnejas, Litorīnas jūras, Baltijas ledus ezera un Ziemeḷkursas augstienes glaciofluviālo nogulumu zona) pētīts oligomezotrofo sauso priežu mežu (Vacciniosa un Myrtillosa) sugu sastāvs, augsnes fizikālās un kịmiskās īpašības, kā arī mežu produktivitāte. Vecākās sauszemes vecuma zonās (Baltijas ledus ezera nogulumi, Ziemeḷkursas augstiene) ir lielāka sugu dažādība koku stāvā un augsnēm izteiktāks podzolēšanās process, savukārt jaunākās sauszemes vecuma zonās (nosusinātā ezerdobe, Mia, Limnejas un Litorīnas jūras stadijas) ir lielāka sugu dažādība zemsedzē (lielāks graudzāḷu un grǐșlu īpatsvars), augsnēm raksturīgs izteiktāks glejošanās process, kā arī ievērojami augstāka kokaudzes produktivitāte. Vecāko sauszemes zonu priežu mežos dominē klases Vaccinio-Piceetea rakstursugas, turpretim jūras piekrastes priežu mežiem (Mia nogulumu zona) raksturīgas klases Pulsatillo-Pinetea sugas. 